way to meet faculty research needs and to use indirect cost funds to visibly and directly affect individual faculty research projects which generate those indirect cost funds. It provides the libraries with a highly visible service which is available only to faculty and may be used by departments as one more way to attract outstanding new research faculty to the university.

\title{
ACRL officers for 1987-88
}

\section{The official ACRL election results.}

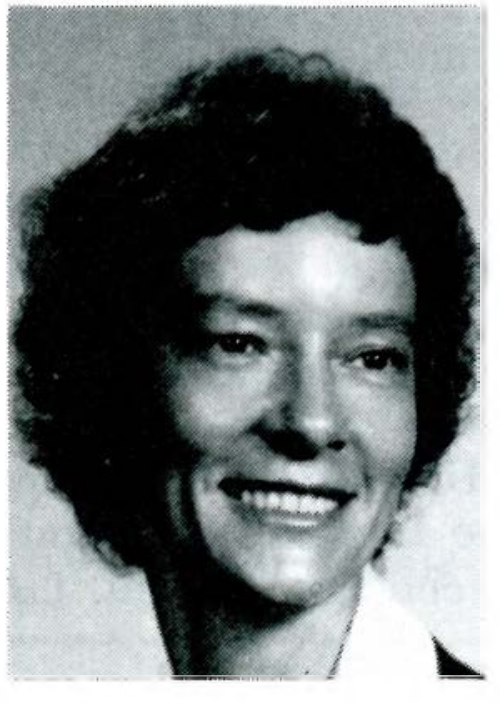

Joanne Euster

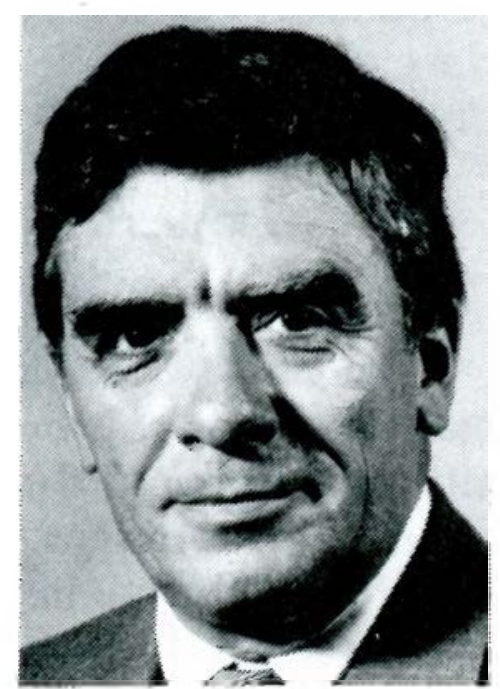

Joseph Boissé
JoAnNe R. Euster, director of libraries at Rutgers, the State University of New Jersey (New Brunswick, NJ 08903), is the fiftieth president of the Association of College and Research Libraries. During her one-year term of office, she will preside over the ACRL Board of Directors and the ACRL Executive Committee. She will chair the ACRL Conference Program Planning Committee for the 1988 Annual Conference in New Orleans and will plan ACRL's major program at the conference.

As president of the division, Euster will represent ACRL on the ALA New Orleans Conference Program Planning Committee and the ALA Planning and Budget Assembly. She will also represent ACRL and ALA in their relations with other organizations. Euster has been very active in ALA and has served as chair of ACRL's Publications Committee from 1982 to 1986 and on the ALA Committee on Standards.

JOSEPH A. BoIsSÉ, university librarian at the Uni- versity of California, Santa Barbara (Santa Barbara, CA 93106), has been elected vicepresident/president-elect of the Association of College and Research Libraries. The 1987 election results showed 1,204 votes for Boissé and 1,166 for Joan Chambers, director of libraries at Colorado State University, Fort Collins, CO 80523.

As vice-president/president-elect of ACRL, Boisse will serve on the ACRL Board of Directors and the ACRL Executive Committee. He will chair the ACRL Conference Program Planning Committee for the 1989 Annual Conference in Dallas. He will represent ACRL on the ALA Appointments Committee and the ALA Conference Program Planning Committee for the 1989 Conference. At the end of the 1988 Annual Conference he will become ACRL's fifty-first president.

Boissé has served on several ACRL committees, including the Legislation, Continuing Education, and Appointments and Nominations Committees. He was a member of the ACRL Task Force on Libraries in Higher Education in 1982-1984 and the LAMA Board of Directors in 1980-1982.

The results of the ACRL elections follow. For each position, the elected candidate is listed first. The number of votes earned by each candidate is given in parentheses.

\section{ACRL Board of Directors}

Director-at-Large (four-year term): PETER MALANCHUK, Chairman, Department of Reference and Bibliography, University of Florida, Gainesville, FL 32611 (1,212); Charles Fineman, Humanities Bibliographer, Northwestern University, Evanston, IL 60201 (982). 
Director-at-Large (four-year term): LARRY HARDESTY, Director of Library Services, Eckerd College, St. Petersburg, FL 33733 (1,296); Norma Yueh, Director of Library Services, Ramapo College, Mahwah, NJ 07430 (910).

\section{Anthropology and Sociology Section}

Vice-Chair/Chair-Elect: STEPHEN E. MACLEOD, Social Sciences Bibliographer, Stanford University, Stanford, CA 94305 (95); write-in (5).

Secretary: Deborah A. Kane, Social Science Reference Librarian, University of Nebraska at Omaha, Omaha, NE 68182 (67); Cheryl C. Kugler, Head of Monograph Services, Vanderbilt University, Nashville, TN 37205 (37).

Member-at-Large: Jo KIBBEE, Anthropology Subject Specialist, University of Illinois, Urbana, IL 61801 (58); Virginia F. Moreland, Computer Search Coordinator, University of NebraskaLincoln, Lincoln, NE 68588 (45).

\section{Art Section}

Vice-Chair/Chair-Elect: Charles R. SMith, Humanities Reference Librarian, Texas A\&M University, College Station, TX 77843 (55); Richard E. Friedman, Director, Art and Architecture Librarian, Auburn University, Auburn, AL 36849 (49).

Secretary: Stephen Allan Patrick, Head, Documents Department, East Tennessee State University, Johnson City, TN 37614 (54); Micheline Nilsen, Creative Arts Librarian, Montana State University, Bozeman, MT 59717 (51).

\section{Asian and African Section}

Vice-Chair/Chair-Elect: BASIMA Q. BEZIRGAN, Middle East Cataloger, University of Chicago, Chicago, IL 60637 (58); Katharine K. Elsasser, Head, Humanities I Section, Subject Cataloging Division, Library of Congress, Washington, DC 20540 (25).

Member-at-Large: Eleanor Murphy Daniel, Head, Black Studies Library, Ohio State University, Columbus, OH 43210 (48); Robert B. Marks Ridinger, Sociology/Anthropology Subject Specialist, Northern Illinois University, DeKalb, IL 60115 (36).

\section{Bibliographic Instruction Section}

Vice-Chair/Chair-Elect: DAvid N. KING, Graduate School of Library and Information Science, University of Illinois, Urbana, IL 61801 (376); Donald J. Kenney, Head, General Reference Department, Virginia Tech University, Blacksburg, VA 24061 (360).

Secretary: SHARON MADER, Information Retrieval Librarian, Memphis State University, Memphis, TN 38152 (442); Katherine Branch, Head, Access Services, Welch Medical Library, Baltimore, MD 21205 (279).

Member-at-Large: ELILN BRoIDY, Coordinator of Library Education Services, University of California, Irvine, CA 92713 (441); Ree De Donato, Head, General Reference Center, Bobst Library, New York University, New York, NY 10012 (293).

\section{College Libraries Section}

Vice-Chair/Chair-Elect: Eleanor H. Pinkham, Director of Library and Media Services, Kalamazoo College, Kalamazoo, MI 49007 (260); Janice C. Fennell, Director of Libraries, Georgia College, Milledgeville, GA 31061 (182).

Secretary: LARRY HARDESTY, Director of Library Services, Eckerd College, St. Petersburg, FL 33733 (239); Daniel W. Lester, Library Director, Fort Lewis College, Durango, CO 81301 (204).

\section{Community and Junior College Libraries Section}

Vice-Chair/Chair-Elect: SHIRLEY A. Lowman, Library Technical Services Director, Maricopa Community College, Phoenix, AZ 85006 (137); Billy C. Beal, Acquisitions Librarian, Meridian Junior College, Meridian, MS 39305 (44).

Secretary: MADISON MOSLEY, Director of Learning Resources, South Florida Community College, Avon Park, FL 33825 (125); Louise Marsen, Media Specialist, Brookdale Community College, Lincroft, NJ 07738 (57).

\section{Education and Behavioral Sciences Section}

Vice-Chair/Chair-Elect: NANCY O'Brien, Associate Professor of Library Administration, University of Illinois, Urbana, IL 61801 (175); Inge Kauffman, Director of the Library, California School of Professional Psychology, Fresno, CA 93710 (102).

Secretary: TARA Lynn Fulton, Reference Instruction Librarian, Loyola University, Chicago, IL 60626 (148); Julie Czisny, Head of Special Collections, Villanova University, Villanova, PA 19085 (133).

\section{Law and Political Science Section}

Vice-Chair/Chair-Elect: Carole A. LARson, Social Sciences Reference Librarian, University of Nebraska at Omaha, Omaha, NE 68182 (86); Earl Shumaker, Head, Government Publications/Microforms, Northern Illinois University, DeKalb, IL $60115(5.5)$.

Secretary: Christine E. Thompson, Head, Original Cataloging Department, Texas A\&M University, College Station, TX 77843 (79); Susan Shiroma, Documents Librarian, Bobst Library, New York University, New York, NY 10012 (57).

Member-at-Large (two-year term): SANDRA S. Coleman, Deputy Librarian, Harvard Law School, Cambridge, MA 02138 (90); Eric M. Wedig, Government Documents Librarian, Memphis State University, Memphis, TN 38152 (52). 


\section{Rare Books and Manuscripts Section}

Vice-Chair/Chair-Elect: WILLIAM L. JoYCE, Associate University Librarian for Rare Books and Special Collections, Princeton University, Princeton, NJ 08540 (234); Ellen S. Dunlap, Director, Rosenbach Museum and Library, Philadelphia, PA 19103 (183).

Secretary: LISA BROWAR, Curator of Rare Books and Manuscripts, Vassar College, Poughkeepsie, NY 12601 (256); Philip A. Metzger, Curator of Special Collections, Lehigh University, Bethlehem, PA 18015 (150).

Member-at-Large (three-year term): Dianne M. Chilmonczyk, Head, Special Collections, Catalog Section, Stanford University, Stanford, CA 94305 (228); Cathy Henderson, Research Librarian, Harry Ransom Humanities Research Center, University of Texas at Austin, Austin, TX 78713 (169).

\section{Science and Technology Section}

Vice-Chair/Chair-Elect: Laura M. Osegueda, Agriculture and Life Sciences Librarian, North Carolina State University, Raleigh, NC 27685 (205); Susanne Redalje, Head, ChemistryPharmacy Library, University of Washington, Seattle, WA 98195 (122).

Secretary: BARBARA A. KAUTz, Entomology, Fisheries and Wildlife Librarian, University of Minnesota, St. Paul, MN 55108 (196); Dorothy McGarry, Head, Catalog Section, Physical Sciences and Technology Libraries, University of California, Los Angeles, CA 90024 (136).

\section{Slavic and East European Section}

Vice-Chair/Chair-Elect: Barbara A. Galik,
Head, Slavic and East European Section, University of Washington, Seattle, WA 98103 (30); G. Koolemans Beynen, Slavic Cataloger, Ohio State University, Columbus, OH 43210 (10).

Secretary: Allan Urbanic, Librarian for Slavic Collections, University of California, Berkeley, CA 94720 (24); Harold M. Leich, Slavic Acquisitions Librarian, University of Illinois, Urbana, IL $61801(16)$.

Member-at-Large: AleXandra Filippenko, Slavic Librarian, University of California, Santa Barbara, CA 93106 (28); Donna A. Canevari de Paredes, Slavic Bibliographer, University of Sasketchewan, Saskatoon, Sask., Canada S7N oW0 (13).

\section{University Libraries Section}

Vice-Chair/Chair-Elect: Karen S. SEIBERT, Associate University Librarian for Public Services, University of North Carolina at Chapel Hill, Chapel Hill, NC 27514 (900); Charles B. Osburn, Dean of Libraries, University of Alabama, Tuscaloosa, AL 35487 (713).

\section{Western European Specialists Section}

Vice-Chair/Chair-Elect: JoHn B. Dillon, European Humanities Bibliographer, University of Wisconsin, Madison, WI 53706 (80); Eva Sartori, Humanities/Social Sciences Librarian, University of Nebraska-Lincoln, Lincoln, NE 68588 (75).

Secretary: Ceres B. Birkhead, Foreign Languages Cataloger, Louisiana State University, Baton Rouge, LA 70803 (79); W. David Rozkuszka, Foreign Document Librarian, Stanford University, Stanford, CA 94305 (68).

Member-at-Large: John Bell Henneman JR.,

\section{Exhibition Catalogue Awards now endowed by the Leabs}

Katharine Kyes Leab and Daniel J. Leab have provided an endowment for the Rare Books and Manuscripts Section's Awards for Exhibition Catalogues. The amount of the endowment is $\$ 8,000$, the interest of which will go to maintain and support the Awards program. Henceforth the name of the Awards will be the Katharine Kyes Leab and Daniel J. Leab American Book Prices Current Awards.

The Leabs, of Washington, Connecticut, have been involved with RBMS activities for many years through their work as editors and publishers of American Book Prices Current, a reference work for buying, selling and evaluating rare materials. Their expertise has made them frequently called upon speakers and workshop leaders at Section preconferences. In response to the security concerns of special collections librarians they developed BAMBAM (Bookline Alert! Missing Books And Manu- scripts) a database system which alerts librarians and dealers of stolen items.

The Leabs will receive one copy of all the catalogues submitted for the Awards. The Exhibition Catalogue Awards are given on an annual basis with entries for the third year (catalogues published in conjunction with an exhibition containing books or manuscripts between September 1, 1986, and August 31, 1987) due by September 30, 1987. Awards are made in three divisions-expensive, moderate, and inexpensive-based on the unit cost of the catalogues. Institutions in the United States and Canada are eligible to apply. Entry forms may be obtained by calling or writing Sally Leach, Chair, RBMS Committee of Awards for Exhibition Catalogues, HRHRC, P.O. Box 7219, The University of Texas at Austin, Austin, TX 78713; (512) 471-9115. 
History Bibliographer, Princeton University, Princeton, NJ 08544 (79); Louis A. Pitschmann, Associate Director for Collection Development, University of Wisconsin, Madison, WI 53706 (68).

\section{Women's Studies Section}

Chair: Ellen Broidy, Coordinator of Library Education Services, University of California, Irvine, CA 92717 (48); Ruth Dickstein, Reference Librarian, University of Arizona, Tucson, AZ 85721 (41).

Vice-Chair/Chair-Elect: BETH STAFFord, Women's Studies Librarian, University of Illinois,
Urbana, IL 61801 (59); Susan G. Williamson, Social Sciences Librarian, Swarthmore College, Swarthmore, PA 19081 (31).

Secretary: BETH Ellen WoodARD, Social Sciences/Humanities Librarian, Michigan State University, East Lansing, MI 48824 (68); Bernice K. Lacks, Head of Readers Services, Vassar College, Poughkeepsie, NY 12601 (17).

Member-at-Large: Mary Lou GoOdyeAR, Assistant Director for Instruction and Research Services, Auraria Library, Denver, CO 80204 (48); Jacquelyn Marie, Reference Librarian, University of California, Santa Cruz, CA 95064 (36).

\section{Samuel Lazerow Fellowship}

The Samuel Lazerow Fellowship for research in acquisitions or technical services in an academic or research library is jointly sponsored by ACRL and the Institute for Scientific Information (ISI). The fellowship honors a senior vice-president of ISI who made outstanding contributions to these fields. Its purpose is to foster advances in acquisitions or technical services by providing practicing librarians in those fields a fellowship for research, travel, or writing. The fellowship consists of an award of $\$ 1,000$ and an appropriate citation. The winner will be announced in New Orleans at ALA Annual Conference in 1988.

Eligibility. To be eligible, librarians need not be working in acquisitions or technical services in an academic or research library. Nor do they need to be members of ACRL.

Submission procedures. Proposals should be submitted to Mary Ellen K. Davis, Program Officer, ACRL/ALA, 50 East Huron Street, Chicago, IL 60611-2795, by December 1, 1987. The proposal should be brief (five pages or less, double-spaced) and include the following:

1) Description of research, travel or writing project.

2) Schedule for project.

3) Estimate of expenses (e.g., professional travel, computer time, photocopying, typing).

Criteria. The proposals will be judged with an emphasis on the following:

1) Potential significance of the project to acquisitions or technical services work.

2) Originality and creativity.

3) Clarity and completeness of the proposal.

4) Evidence of an interest in scholarship, such as a previous publication record.

Recipients of the fellowship will be asked to submit a brief report of the results of their research.

The winner of the 1987 Lazerow Fellowship was Margaret Ann Johnson, head of technical services at the University of Minnesota, St. Paul, to study the different methods of implementing technological changes in libraries and the relative success of each program.

\section{Miriam Dudley BI Librarian of the Year Award}

The ACRL Bibliographic Instruction Section (BIS) invites nominations for the Miriam Dudley Bibliographic Instruction Librarian of the Year Award, sponsored by Mountainside Publishing on behalf of their publication, Research Strategies.

This award, which carries a cash prize of $\$ 900$, honors Miriam Dudley whose pioneering efforts in the field of bibliographic instruction led to the formation of ACRL's Bibliographic Instruction Section.
Individuals nominated should have achieved distinction in such areas as planning and implementation of a bibliographic instruction program that has served as a model for other programs; development of courses on bibliographic instruction in ALA-accredited library schools, or development of continuing education courses on bibliographic instruction that have served as models for other courses; research and publication that has had demonstrable impact on the concepts and methods of 


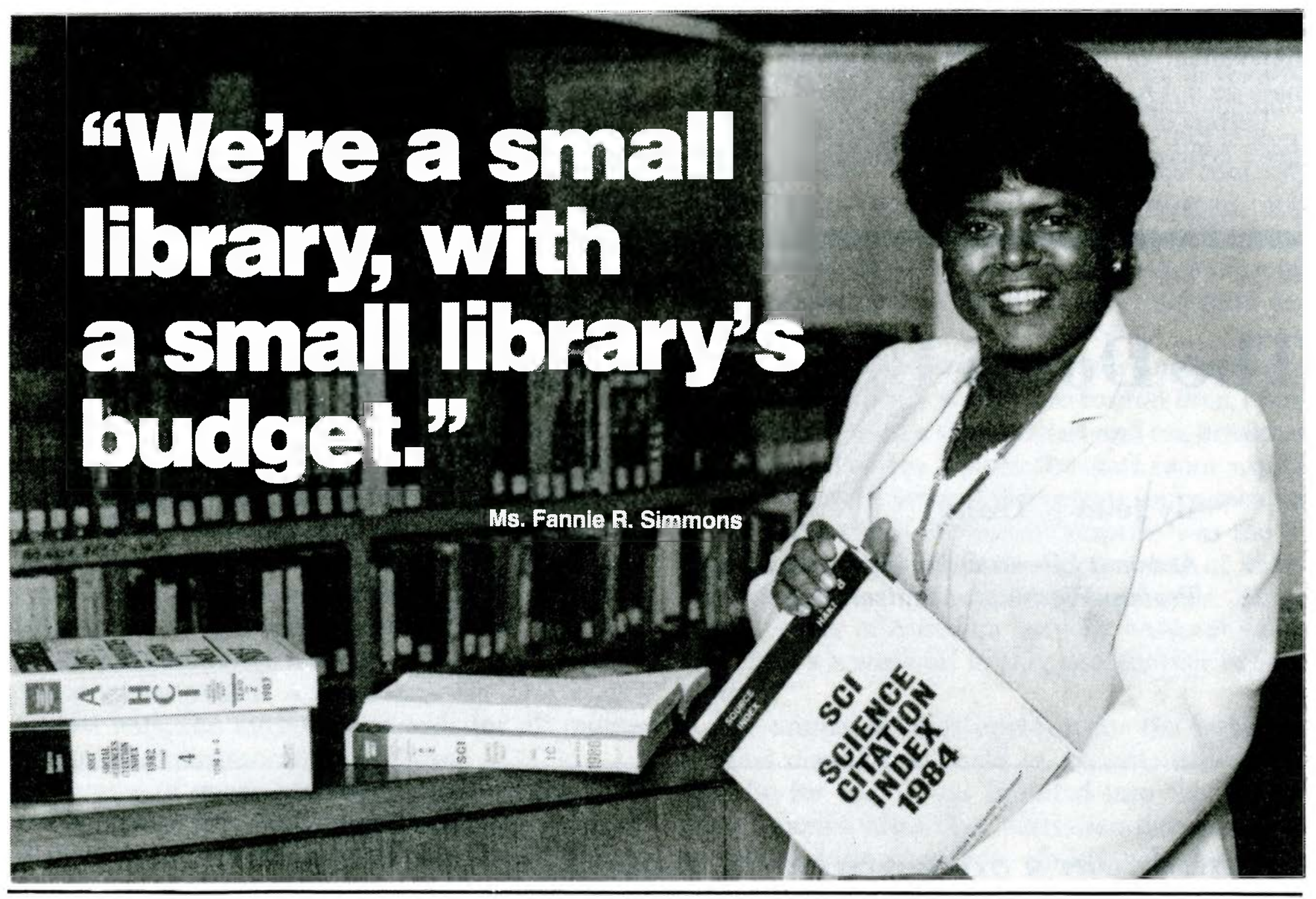

"But thanks to the ISI" Library Grant Program, we can afford the big library coverage of the Science Citation Index", the Social Sciences Citation Index", and the Arts \& Humanities Citation Index.".

Ms. Fannie R. Simmons, Acting Director of Public Services, Robert W. Woodruff Library of Atlanta University Center. The Woodruff Library serves the following institutions: Atlanta University; Clark, Morris Brown and Spelman Colleges: Interdenominational Theological Center: and AU Center, Inc. It also shares its services with the Morehouse School Medicine.

For over ten years, the ISI Library Grant Program has been helping "small" libraries just like yours purchase ISl's major indexes at discounts of 25 to 75 percent off the regular price. Today, libraries at California State College at Chico, Massachusetts General Hospital, Middlebury College, the Minneapolis Public Library, Portsmouth Polytechnic in England, University of llorin in Nigeria, and Universiti Teknologi Malaysia are just a few of the institutions that own ISI indexes as a direct result of these discounts. Thanks to the ISI Library Grant Program, these libraries can now afford the thorough, precise literature search capabilities of the Science Citation Index, the Social Sciences Citation Index, and the Arts \& Humanities Citation Index. To date, more than 700 libraries worldwide have received approximately two million dollars in grants.

Isn't it time your library discovered the ISI Library Grant Program? To find out how your library can qualify, just mail the coupon. We'll send you a free, no-obligation evaluation form that will help us determine your library's eligibility. Or, if you'd like more information about the ISI Library Grant Program, call our Customer Services Department at 800523-1850, extension 1405. In Pennsylvania, call collect 215-386-0100, extension 1405.

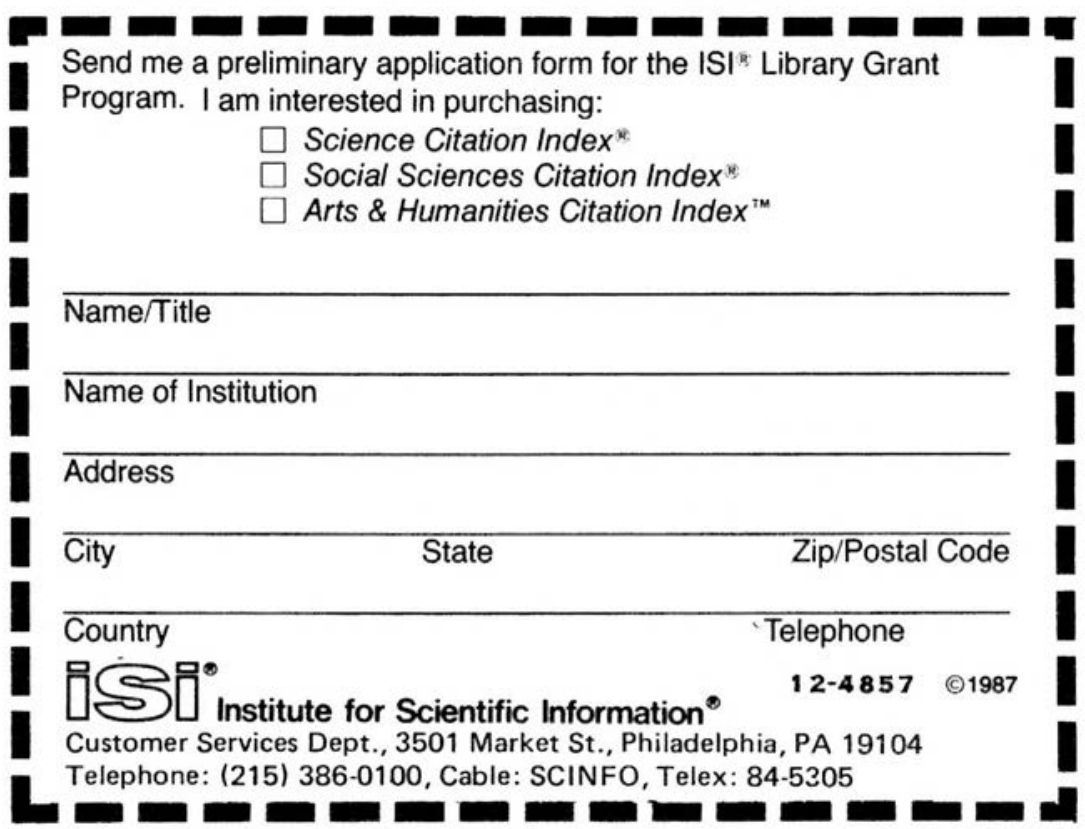


teaching bibliography; and/or active participation in organizations devoted to the promotion and enhancement of bibliographic instruction. (Nominees do not have to meet all of the stated criteria.)

Letters of nomination should outline the nominee's achivements according to the above criteria and, if possible, a curriculum vitae of the nominee should be attached. Nominations should be sent no later than December 1, 1987, to Betsy Baker, Bibliographic Instruction Services Librarian, Northwestern University Library, 1935 Sheridan Road, Evanston, IL 60201; (312) 491-7656.

\title{
The Down Under experience
}

\author{
By Joan I. Tracy \\ Assistant Librarian for Technical Services \\ Eastern Washington University
}

\section{A cataloger's adventures in Australia.}

$\mathbf{M}$ Library of the University of Queensland resulted from inquiries to Australian libraries that had been listed in C\&RL News as potential exchange institutions. Because of my administrative responsibilities, I could not offer an exchange of positions, but I was willing to work in any professional capacity in technical services. In turn, the Eastern Washington University Library would offer a position in technical services with an emphasis on cataloging.

My inquiries elicited a reply from the deputy librarian at the University of Queensland, who indicated that Gillian Meteyard, a cataloger at the Central Library, was interested in an exchange. After the exchange was approved, Gillian and I then corresponded to arrange a swap of our homes and the use of our cars for April through September 1986.

The technical services staff of about 60 in Queensland's Central Library performs the familiar tasks of ordering, cataloging and processing library materials. The large staff, in contrast to similar libraries in the United States, is a result of the policy of hiring full-time employees to do much of the work that is performed by part-time student assistants in American academic libraries.

The catalogers are organized into teams, with each group responsible for several subject areas so that the workload is equitably distributed. I was a member of the "Purple" team that processed all materials for the Q-QE, HA-HG, and PC class numbers of the Library of Congress schedule. The team included two librarians and two library assistants. The group processed all orders and cataloged all materials, including serials, government documents and audiovisual items (the latter from surrogates prepared by other staff). However, I cataloged only monographs.

The use of AACR2 and the Library of Congress classification and subject headings made it relatively easy for me to jump right in and make myself useful. However, it took me a while to learn local practice, including such minor details as entering a date in the Australian pattern with the day first, and writing the LC call number in a different format. The team leader, the two library assistants, and everyone in the cataloging area were forgiving of my errors and always ready to answer my questions.

When I first began work that April, cataloging was obtained from the Australian National Library (ANL) by matching search keys: ISBN, LC card number, author and title. However, a few months later the cataloging teams began to access 